\title{
KEMAMPUAN LITERASI MATEMATIKA PADA DISCOVERY LEARNING PENDEKATAN RME BERDASARKAN GAYA BELAJAR SISWA KELAS V
}

\section{MATHEMATICAL LITERATION ABILITY IN THE DISCOVERY LEARNING APPROACH TO RME BASED ON CLASS V STUDENT LEARNING STYLE}

\author{
Kristi Liani Purwanti ${ }^{1}$, Zuanita Adriyani ${ }^{2}$ \\ ${ }^{1,2}$ UIN Walisongo \\ 1,2Jl. Prof. Dr. Hamka Semarang 50185 Kampus II, (024) 7601295 \\ Email: kristi_liani@walisongo.ac.id ${ }^{1}$,zuanita_adriyani@walisongo.ac.id ${ }^{2}$
}

\begin{abstract}
Abstrak
Pembelajaran matematika perlu dirancang untuk mendorong siswa memiliki kemahiran matematis, seperti kemampuan pemahaman, komunikasi, koneksi, penalaran dan pemecahan masalah matematis. Kemampuan itu diperlukan supaya siswa dapat menerapkan dan memanfaatkan informasi matematika dalam kehidupan sehari-hari. Hal tersebut sejalan dengan literasi matematika. Literasi matematika menurut OECD (2016), didefinisikan sebagai kapasitas untuk mengenal dan memahami peran matematika di dunia, memecahkan masalah matematika dalam berbagai konteks, menafsirkan pernyataan matematika, dan menerapkan matematika secara rasional. Tujuan dari penelitian ini adalah untuk mengetahui kemampuan literasi matematika siswa ditinjau dari gaya belajar Kolb siswa kelas $\mathrm{V}$ Madrasah Ibtidaiyah dengan pembelajaran discovery learning pendekatan RME. Metode penelitian yang dipakai adalah kualitatif deskriptif. Adapun hasil dari penelitian adalah dilihat dari 7 indikator dalam literasi matematika bahwa gaya belajar siswa tipe accommodator lebih baik dibandingkan gaya belajar lainnya. Gaya belajar assimilator dan diverger kemampuan literasi matematika siswa hampir sama tetapi gaya belajar converger paling rendah dibandingkan dari assimilator dan diverger.
\end{abstract}

Kata Kunci: Kemampuan Literasi Matematika, Gaya belajar, Siswa kelas V

\begin{abstract}
Mathematics learning needs to be designed to encourage students to have mathematical skills, such as the ability to understand, communicate, connect, reason and solve mathematical problems. Capability is needed so students can apply and utilize mathematical information in their daily lives. This is in line with mathematical literacy. Mathematical literacy according to the OECD (2016), is defined as the capacity to recognize and understand the role of mathematics in the world, solve mathematical problems in various contexts, interpret mathematical statements, and apply mathematics rationally. The purpose of this study was to determine the students' mathematical literacy skills in terms of Kolb's learning style of class V Ibtidaiyah Madrasas with discovery learning learning the RME approach. The research method used is descriptive qualitative. The results of the study are seen from 7 indicators in mathematical literacy that the accommodator type of student learning style is better than other learning styles. The assimilator learning style and the students' mathematical literacy abilities combined were similar but the lowest converger learning style was compared to the assimilator and diverger.
\end{abstract}

Keyword: Mathematical Literacy Ability, Learning Style, Students of Class V 


\section{Pendahuluan}

Pembelajaran di sekolah dasar atau madrasah ibtidaiyah merupakan pembelajaran yang sangat penting, sebab sebagai fondasi pendidikan. Pembelajaran yang diajarkan tidak boleh asal-asalan. Pembelajaran aktif kreatif efektif dan menyenangkan serta aspek kognitif, afektif, psikomotorik perlu juga dalam pembelajaran di sekolah dasar. Pembelajaran di sekolah dasar salah satunya pembelajaran matematika.

Junaedi \& Asikin (2012) menjelaskan pembelajaran matematika perlu dirancang untuk mendorong siswa memiliki kemahiran matematis, seperti kemampuan pemahaman, komunikasi, koneksi, penalaran dan pemecahan masalah matematis. Kemampuan itu diperlukan supaya siswa dapat menerapkan dan memanfaatkan informasi matematika dalam kehidupan sehari-hari. Hal tersebut sejalan dengan literasi matematika.

Pembelajaran matematika menurut kurikulum mempunyai tujuan mengembangkan kemampuan problem solving, kemampuan komunikasi, kemampuan penalaran, kemampuan berfikir kritis, kemampuan berfikir kreatif, kemampuan koneksi, dan kemampuan literasi. Literasi matematika menurut OECD (2016), didefinisikan sebagai kapasitas untuk mengenal dan memahami peran matematika di dunia, memecahkan masalah matematika dalam berbagai konteks, menafsirkan pernyataan matematika, dan menerapkan matematika secara rasional. Termasuk kemampuan melakukan penalaran secara matematis dan menggunakan konsep, prosedur, fakta, sebagai alat untuk mendeskripsikan, menjelaskan serta memprediksi suatu fenomena atau kejadian. Literasi matematika dapat membantu individu untuk mengenal peran matematika di dunia nyata dan sebagai dasar pertimbangan dan penentuan keputusan yang dibutuhkan oleh masyarakat (OECD, 2010: 4). Sebuah laporan dari Indeks Pembangunan Manusia (IPM) survei United Nations Development Programme (UNDP) menunjukkan bahwa IPM Indonesia adalah 0.600 pada tahun 2010 dan peringkat 108 dari 169 negara (Klugman, 2010: 154). Masyarakat Indonesia masih menghadapi masalah sulit, terutama yang berkaitan dengan mutu pendidikan, relevansi, dan efisiensi (Kurikulum, 2007). Kualitas pendidikan suatu negara sangat digunakan untuk mengukur pembangunan negara. Hall dan Matthews (2008) menunjukkan bahwa aspek pendidikan memiliki peran penting terhadap kemajuan suatu negara. Peringkat Indonesia dalam matematika menurut PISA yaitu peringkat 39 dari 40 negara pada tahun 2003, peringkat 38 dari 41 negara pada tahun 2006, dan peringkat 61 dari 65 negara pada tahun 2009 (Kunandar; 2009: 2). Kemampuan literasi matematika di Indonesia belum berkembang, sehingga di sekolah dasar perlu diperhatikan. Pembelajaran matematika di sekolah dasar perlu ditumbuhkan kemampuan literasi matematika, salah satu upaya yaitu pembelajaran disvocery learning dengan pendekatan realistis atau RME. Pembelajaran ini akan diterapkan di kelas $\mathrm{v}$ madrasah ibtidaiyah agar benar-benar bahwa kemampuan literasi matematika tumbuh dijiwa siswa. Pembelajaran matematika di sekolah dasar perlu ditumbuhkan kemampuan literasi matematika, salah satu upaya yaitu pembelajaran disvocery learning dengan pendekatan realistis atau RME. Pembelajaran ini akan diterapkan di kelas $\mathrm{v}$ madrasah ibtidaiyah agar benar-benar bahwa kemampuan literasi matematika tumbuh dijiwa siswa.

Literasi matematika berarti kapasitas untuk mengenal dan memahami peran matematika di dunia, memecahkan masalah dalam berbagai konteks, menafsirkan pernyataan matematika, dan menerapkan matematika secara rasional. The 
Organixzation for Economic Cooperation and Development (OECD, 2016) menyebutkan bahwa definisi literasi matematika dapat dianalisis dalam tiga aspek yang saling berkaitan, dalam penelitian ini hanya satu aspek proses yaitu: (a) Communication (Komunikasi), literasi matematika melibatkan komunikasi individu merasakan adanya beberapa tantangan dan dirangsang untuk mengenali dan memahami situasi masalah. Membaca, memecahkan kode dan menafsirkan pernyataan, pertanyaan, tugas atau benda memungkinkan individu untuk membentuk model mental dari situasi, yang merupakan langkah penting dalam memahami, menjelaskan dan merumuskan masalah. Selama proses solusi, hasil antara mungkin perlu diringkas dan disajikan. Kemudian, setelah solusi telah ditemukan, pemecah masalah mungkin perlu untuk menyajikan solusi, dan mungkin penjelasan atau pembenaran, kepada orang lain. (b) Mathematising, literasi matematika dapat melibatkan mengubah masalah didefinisikan dalam dunia nyata ke bentuk matematika tepat (yang dapat mencakup penataan, membuat konsep, membuat asumsi, dan / atau merumuskan model), atau menafsirkan atau mengevaluasi hasil matematika atau model matematika sehubungan dengan masalah asli. The mathematising istilah digunakan untuk menggambarkan kegiatan matematika dasar yang terlibat. (c) Representation, literasi matematika sangat sering melibatkan representasi objek matematika dan situasi. Hal ini dapat memerlukan memilih, menafsirkan, menerjemahkan antara, dan menggunakan berbagai representasi untuk menangkap situasi, berinteraksi dengan masalah, atau untuk mempresentasikan karya seseorang. Representasi dimaksud mencakup grafik, tabel, diagram, gambar, persamaan, rumus, deskripsi tekstual, dan bahan beton. (d) Reasoning and argument (penalaran dan argumen), sebuah kemampuan matematika yang disebut di seluruh tahap dan kegiatan yang berhubungan dengan keaksaraan matematika yang berbeda disebut sebagai penalaran dan argumentasi. Kemampuan ini melibatkan logis berakar proses berpikir yang mengeksplorasi dan elemen masalah hubungan sehingga membuat kesimpulan dari mereka, periksa justifikasi yang diberikan, atau memberikan pembenaran dari pernyataan atau solusi untuk masalah (d) Devising strategies for solving problems (merumuskan strategi untuk memecahkan masalah), literasi sering memerlukan strategi merancang untuk memecahkan masalah matematis. Ini melibatkan serangkaian proses kontrol kritis yang memandu seorang individu untuk secara efektif mengenali, merumuskan dan memecahkan masalah. Keterampilan ini ditandai sebagai memilih atau merancang rencana atau strategi untuk menggunakan matematika untuk memecahkan masalah yang timbul dari suatu tugas atau konteks, serta membimbing pelaksanaannya. Kemampuan matematika ini dapat diminta pada setiap tahapan proses pemecahan masalah. (7) Using symbolic, formal and technical language and operations (Menggunakan simbolik, bahasa formal dan teknis dan operasi), literasi matematika membutuhkan menggunakan simbolik, bahasa dan operasi formal dan teknis. Hal ini melibatkan pemahaman, menafsirkan, memanipulasi, dan membuat penggunaan ekspresi simbolik dalam konteks matematika (termasuk ekspresi aritmatika dan operasi) diatur oleh konvensi matematika dan aturan. Hal ini juga melibatkan pemahaman dan memanfaatkan konstruksi formal berdasarkan definisi, aturan dan sistem formal dan juga menggunakan algoritma dengan entitas tersebut. Simbol, aturan dan sistem yang digunakan akan bervariasi sesuai dengan apa isi pengetahuan matematika tertentu diperlukan untuk tugas tertentu untuk merumuskan, memecahkan atau menafsirkan matematika. (8) Using mathematical tools (Menggunakan alat-alat matematika), 
kemampuan matematika akhir yang mendukung keaksaraan matematika dalam prakteknya menggunakan alat matematika. alat-alat matematika meliputi alat-alat fisik seperti alat ukur, serta kalkulator dan alat berbasis komputer yang semakin banyak tersedia. Kemampuan ini melibatkan mengetahui tentang dan mampu memanfaatkan berbagai alat yang dapat membantu aktivitas matematika, dan mengetahui tentang batasan alat tersebut. alat-alat matematika juga dapat memiliki peran penting dalam mengkomunikasikan hasil.

Pembelajaran ini berdasarkan penemuan, konstruktivis dan teori bagaimana belajar. Menurut Syah (2016), ada 6 tahapan pembelajaran discovery learning yaitu stimulation, problem statement, data collection, data processing, verification, generalization. Pembelajaran matematika dengan pendekatan realistik mempunyai kelebihan, diantaranya menuntun siswa dari keadaan yang konkrit serta menggunakan dunia nyata sebagai titik pangkal permulaan dalam pengembangan konsep-konsep dan gagasan matematika. Melalui pendekatan realistik, siswa diberikan tugas-tugas mendekati kenyataan sehingga siswa akan memperluas dunia kehidupannya. Langkah-langkah pembelajaran discovery learning berpendekatan RME: (1) Stimulation (pemberian stimulus) yaitu guru mengajukan masalah-masalah yang realistik bagi siswa, yaitu dapat dilihat/dibayangkan oleh siswa (prinsip realitas/ phenomenological exploration). Masalah tersebut diambil dari konten dan konteks literasi matematika yang relevan dengan siswa; (2) Problem statement (pernyataan/identifikasi masalah) yaitu guru mengajak siswa untuk mengidentifikasi masalah yang realistik dengan bahan disajikan untuk stimulus. (prinsip realitas); (3) Data collection (pengumpulan data) yaitu siswa dalam mengumpulkan informasi yang relevan untuk membuktikan atau menemukan suatu konsep. Siswa didorong lebih aktif dan kreatif dalam mengembangkan ide dan strategi (prinsip student contribution); (4) Data processing (pengolahan data) yaitu siswa terlibat secara interaktif, memahami pekerjaan temannya, menjelaskan dalam diskusi kelas, sikapnya setuju atau tidak setuju dengan solusi temannya (interactivity). Siswa mengolah data yang dikumpulkan. Pengolahan data dalam rangka mengarahkan kepada konsep yang akan dicapai. Guru memotivasi siswa agar mampu menyelesaikan pertanyaan-pertanyaan penuntun yang mengarah siswa dalam memperoleh penyelesaian soal. Guru berkeliling dan memberikan bantuan; (5) Verification (memverifikasi) yaitu guru menentukan siswa tertentu atau kelompok tertentu untuk mempresentasikan hasil kerjanya. Selanjutnya hasil dari diskusi kelompok itu dibandingkan pada diskusi kelas dipimpin oleh guru, untuk memformalkan konsep matematika yang ditemukan siswa. Pada tahap ini dapat digunakan untuk melatih keberanian siswa dalam berpendapat, walaupun berbeda dengan teman bahkan dengan guru. Siswa dapat mengecak kebenaran dari konsep yang ditemukan dengan bimbingan guru. Pengembangan pengetahuan informal menjadi konsep formal (bridging by vertical instrument) merupakan suatu proses yang bertahap melalui penggunaan model dan simbol dan dibangun sendiri oleh siswa (prinsip berjenjang); (6) Generalization (penarikan kesimpulan)yaitu struktur dan konsep-konsep matematis yang muncul dari pemecahan masalah realistik itu mengarah ke interwining (pengaitan) antara bagian-bagian materi (prinsip jalinan). Guru mengalokasikan waktu untuk membiasakan siwa dengan soal-soalliterasi matematika. Guru dan siswa bersama-sama menarik keimpulan dari apa yang sudah ditemukan. 
Kolb (2005) menyatakan bahwa dalam proses belajar terdapat dua aspek atau dimensi yakni pengalaman konkrit (CE) pada satu pihak dan koseptualisasi abstrak (AC) pada pihak lain. Dimensi kedua adalah eksperimentasi aktif (AE) pada satu pihak dan observasi reflektif (RO) pada pihak lain. Individu selalu mencari kemampuan belajar tertentu dalam situasi tertentu. Jadi individu dapat beralih dari perlaku (AE) menjadi pengamat (RO), dan dari keterlibatan langsung (CE) menjadi analisa abstrak (AC). Untuk lebih jelas dalam mempelajari klasifikasi gaya belajar Kolb dapat dilihat dalam siklus gaya belajar Kolb.

Pratiwi, et.al (2013) mengatakan deskripsi mengenai indikator perilaku elemen belajar dari David Kolb adalah sebagai berikut (1) Pengalaman konkret yaitu melihat segala sesuatu sebagaiman adanya, dalam detail yang kasar, belajar dari pengalaman spesifik dan data empiris, sensitive terhadap perasaan dan manusia; (2) Observasi reflektif yaitu secara hati-hati melakukan observasi sebelum mengambil keputusan, melihat isu dari berbagai macam perspektif, mencaribmakna dari segala sesuatu; (3) Konseptualisasi abstrak yaitu melihat segala sesuatu sebagai konsep dan ide yang perlu dianalisis secara logis, membuat perencanaan sitematik, bertindak berdasarkan pemahaman intelektual terhadap situasi; (4) Eksperimentasi aktif yaitu menunjukkan kemampuan untuk mengambil tindakan, berani menghadapi resiko, mempengaruhi orang lain melalui tindakan.

Untuk menentukan gaya belajar seseorang, Kolb menciptakan suatu learning style inventory (LSI) dan membedakan 4 tipe gaya belajar yaitu (1) Diverger, kombinasi elemen pengalaman konkrit dan observasi reflektif. Individu dengan gaya belajar ini mampu melihat situasi konkrit dari beragam perspektif. Memiliki minat budaya yang sangat luas serta senang mengumpulkan informasi. Minat sosialnya tinggi, cenderung imajinatif, dan perasaannya amat peka. Dalam situasi belajar formal, lebih suka bekerja dalam kelompok dan menerima umpan balik yang bersifat personal. Mampu mendengar pikiran yang terbuka; (2) Assimilatror, kombinasi konseptualisasi dan observasi reflektif. Individu ini terampil dalam mengolah banyak informasi serta menempatkan kedalam bentuk yang pasti dan logis. Kurang berfokus pada manusia, lebih berminat pada ide dan konsep abstrak. Secara umum lebih mementingkan keunggulan logis sebuah teori dari nilai praktisnya. Dalam situasi belajar formal, lebih suka membaca, mengajar, mengekslorasi model analitis, dan memanfaatkan waktu untuk memikirkan berbagai hal secara mendalam; (3) Converger, kombinasi konseptual abstrak dan eksperimentasi aktif. Individu ini paling baik dalam menemukan kegunaan raktik dari ide dan teori. Mampu memecahkan masalah dan mengambil keputusan secara efektif.dalam situasi belajar formal, cenderung melakukan eksperimen dengan ide baru, simulasi, dan aplikasi praktis; (4) Accommodator, kombinasi pengalaman konkrit dan eksperimentasi aktif. Individu ini memiliki keunggulan untuk belajar dari pengalaman langsung. Sangat suka mengambil tindakan dan melibatkan diri dalam situasi baru yang menantang. Dalam situasi belajar formal, lebih suka bekerja dengan orang lain untuk menyelesaikan tugas, menetapkan tujuan, melakukan kerja lapangan, serta menguji bermacam-macam permasalahan. 


\section{Metode Penelitian}

Penelitian ini menggunakan jenis penelitian kualitatif lapangan, yaitu peneliti berusaha mendeskripsikan dan menganalisis peristiwa, fenomena dan aktivitas sosial, sikap serta pemikiran orang baik individu maupun kelompok. Penelitian ini sama artinya dengan menggunakan pendekatan kualitatif deskriptif, yaitu pendekatan dengan berdasarkan pada semua sumber data yang telah dicatat, dikumpulkan dan disimpulkan (Sudjana, 2009). Teknik pengumpulan data yang digunakan observasi, dokumentasi, wawancara dan tes. Analisi data yan digunakan adalah analisis deskriptif kualitatif, yaitu suatu metode penelitian yang berusaha mendeskripsikan suatu gejala, peristiwa dan kejadian yang terjadi pada saat sekarang (Sudjana, 2009).

\section{Hasil dan Pembahasan}

\subsection{Hasil}

Adapun hasil keseluruhan dari tes kemampuan literasi matematika dapat dilihat tabel berikut.

Tabel 1. Hasil Tes Kemampuan Literasi Matematika

\begin{tabular}{ccc}
\hline No & Kelas & Frekuensi \\
\hline 1 & $36-44$ & 3 \\
\hline 2 & $45-53$ & 2 \\
\hline 3 & $54-62$ & 4 \\
\hline 4 & $63-71$ & 10 \\
\hline 5 & $72-80$ & 13 \\
\hline 6 & $81-89$ & 2 \\
\hline
\end{tabular}

Dari tabel 1, juga disajikan dalam diagram batang sebagai berikut

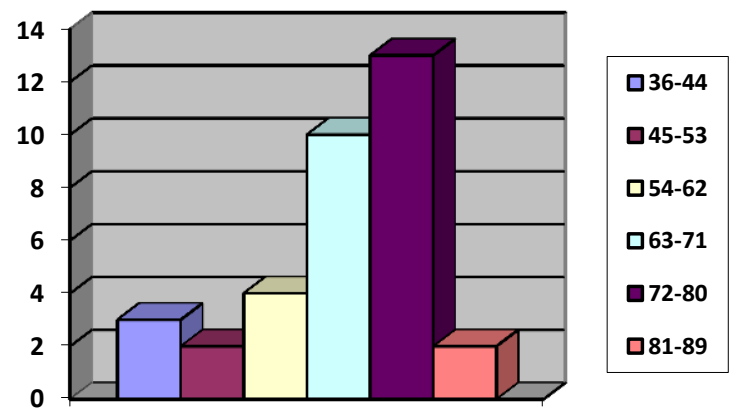

Gambar 1. Hasil tes kemampuan literasi matematika

Berdasarkan tabel 1, terlihat bahwa hasil tes kemampuan literasi matematika kelas $\mathrm{V}$ abdurahman adalah sebagai berikut interval nilai 36-46 ada 4 siswa, interval nilai 47-57 ada 5 siswa, interval nilai 58-68 ada 9 siswa, interval nilai 69-79 ada 14 siswa, interval nilai 80-90 ada 1 siswa, interval nilai 91-101 ada 1 siswa. Rata-rata kemampuan literasi matematika kelas V abdurahman adalah 66,9. 
Hasil tes kemampuan literasi berdasarkan gaya belajar dan gender adalah sebagai berikut ini

Tabel 2. Hasil Tes Kemampuan Literasi Berdasarkan Gaya Belajar Dan Gender

\begin{tabular}{|c|c|c|}
\hline Gaya belajar & Perempuan & Laki-laki \\
\hline \multirow[t]{8}{*}{ Accomodator } & 72 & 85 \\
\hline & 68 & 56 \\
\hline & 76 & 78 \\
\hline & 72 & 40 \\
\hline & 78 & 36 \\
\hline & & 55 \\
\hline & & 76 \\
\hline & 68,41 & 60,85 \\
\hline \multirow[t]{6}{*}{ Assimilator } & 72 & 70 \\
\hline & 64 & 63 \\
\hline & 56 & 64 \\
\hline & 82 & \\
\hline & 78 & \\
\hline & 70,40 & 65,67 \\
\hline \multirow[t]{5}{*}{ Converger } & 68 & 42 \\
\hline & 64 & 55 \\
\hline & 73 & 74 \\
\hline & & 45 \\
\hline & 68,33 & 54,00 \\
\hline \multirow[t]{7}{*}{ Diverger } & 75 & 68 \\
\hline & 50 & \\
\hline & 64 & \\
\hline & 76 & \\
\hline & 76 & \\
\hline & 68 & \\
\hline & 68,16 & 68,00 \\
\hline
\end{tabular}

Dilihat dari tabel 2, bahwa rataan kemampuan literasi matematika siswa dengan gaya belajar tipe accommodator jenis kelamin perempuan didapat 68,41 dan jenis kelamin laki-laki 60,85. Jadi terlihat bahwa rataan kemampuan literasi matematika siswa gaya belajar tipe accommodator siswa perempuan lebih baik dibandingkan laki-laki. Rataan kemampuan literasi matematika siswa dengan gaya belajar tipe assimilator jenis kelamin perempuan didapat 70,40 dan jenis kelamin laki-laki 65,67. Jadi terlihat bahwa rataan kemampuan literasi matematika siswa gaya belajar tipe assimilator siswa perempuan lebih baik dibandingkan laki-laki. Rataan kemampuan literasi matematika siswa dengan gaya belajar tipe converger jenis kelamin perempuan didapat 68,33 dan jenis kelamin laki-laki 54. Jadi terlihat bahwa rataan kemampuan literasi matematika siswa gaya belajar tipe converger siswa perempuan lebih baik dibandingkan laki-laki. Rataan kemampuan literasi matematika siswa dengan gaya belajar tipe diverger jenis kelamin perempuan didapat 68,16 dan jenis kelamin laki-laki 68. Jadi terlihat bahwa rataan kemampuan literasi matematika siswa gaya belajar tipe diverger siswa perempuan lebih baik dibandingkan laki-laki. 


\subsection{Pembahasan}

Kemampuan literasi matematika dipengaruhi oleh gaya belajar siswa. Gaya belajar siswa ada 4 tipe yaitu accommodator, assimilator, diverger and converger, dari keempat gaya belajar tersebut ternyata gaya belajar siswa tipe accommodator lebih baik dibandingkan gaya belajar lainnya. Gaya belajar assimilator dan diverger kemampuan literasi matematika siswa hampir sama tetapi gaya belajar converger paling rendah dibandingkan dari assimilator dan diverger.

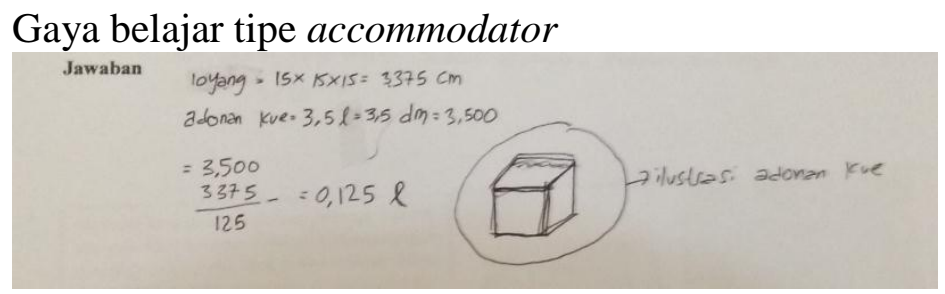

\section{Communication}

Pertemuan pertama siswa belum dapat menyampaikan gagasan dengan benar, setelah 4 kali pertemuan dengan pembelajaran discovery learning pendekatan RME, terlihat aspek communication. Setelah diberi perlakuan, siswa dalam menyatakan gagasan/ ide matematika sesuai dengan masalah yaitu menuliskan gagasan/ide pada soal dengan benar namun kurang lengkap. Siswa dalam memahami, menafsikan dan mengevaluasi gagasan/ ide matematika berkaitan dengan masalah yaitu rumusan benar dalam menjawab volume kubus dan hasilnya benar, perhitungan benar disini saat menyelesaikan tahap terakhir pengurangan volume loyang dengan banyaknya adonan, banyaknya adonan sudah diubah ke satuan yang sama dengan volume loyang atau kubus tersebut.

\section{Mathematising}

Pertemuan pertama siswa dalam mengubah permasalahan dari dunia nyata ke bentuk matematika masih kesusahan. Jawaban yang diberikan tanpa ada langkahnya, hanya berupa angka terakhir untuk jawabannya. Setelah diberi perlakukan secara berulangulang siswa dalam mengerjakan soal dapat mengubah permasalahan dari dunia nyata ke bentuk matematika namun terdapat pendefinisian yang kurang dengan tepat, sudah lebih baik dari sebelumnya.

\section{Representation}

Pada pertemuan pertama siswa belum dapat mempresentasikan jawaban tanpa gambar. Adanya perlakukan pembelajaran discovery learning pendekatan RME, nampak siswa dalam menggambar sketsa kubus yang terdapat pada soal dengan ukuran proporsional sesuai soal tetapi tidak menuliskan panjang rusuk dari kubus tersebut.

\section{Reasoning and argument}

Dari pertemuan satu sampai terakhir, selama diberi perlakuan dalam reasoning and argument belum nampak ada perubahan, siswa belum memberikan kesimpulan untuk mengecek ulang jawaban yang telah dikerjakan. Setelah menjawab dan perhitungan selesai, siswa menganggap selesai sudah pekerjaan.

\section{Devising strategies for solving problems}

Langkah-langkah penyelesaian benar terlihat dari adanya menghitung volume dari loyang, banyaknya adonan terus diubah dari satuan yang tidak sama menjadi sama dengan volume loyang. Dengan satuan yang sama maka dapat dikurangkan volume 
adonan dikurangi volume loyang. Langkah penyelesaian sudah benar, tetapi untuk langkah diketahui dari soal sampai hal yang ditanyakan belum tampak.

\section{Using symbolic, formal and technical language and operations}

Menggunakan simbol, bahasa formal dan bahasa teknis serta operasi hitung untuk merumuskan, memecahkan atau menafsirkan matematika yaitu penulisan huruf/simbol benar, penulisan angka salah, tulisan jelas.

\section{Using mathematical tools}

Dalam perhitungan siswa menggunakan alat bantu perhitungan dengan susun pendek untuk menggurangkan dan mengalikan hasil tersebut.

Gaya belajar tipe assimilator

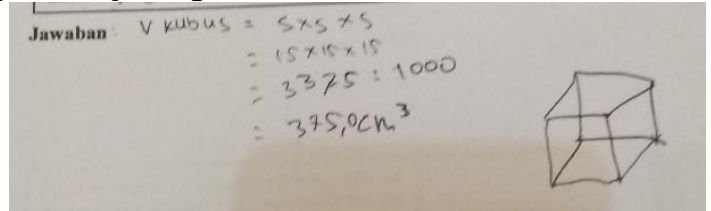

\section{Communication}

Pertemuan pertama siswa belum dapat menyampaikan gagasan dengan benar, setelah 4 kali pertemuan dengan pembelajaran discovery learning pendekatan RME, terlihat aspek communication. Setelah diberi perlakuan, siswa dalam menyatakan gagasan/ ide matematika sesuai dengan masalah yaitu menuliskan gagasan/ide pada soal dengan benar namun kurang lengkap. Siswa dalam memahami, menafsikan dan mengevaluasi gagasan/ ide matematika berkaitan dengan masalah yaitu rumusan benar dalam menjawab volume kubus dan hasilnya benar, merubah satuan volume, tetapi tidak terlihat untuk apa mencari volume, langkah selanjutnya belum ada.

\section{Mathematising}

Pertemuan pertama siswa dalam mengubah permasalahan dari dunia nyata ke bentuk matematika masih kesusahan. Setelah diberi perlakukan secara berulang-ulang siswa dalam mengerjakan soal dapat mengubah permasalahan dari dunia nyata ke bentuk matematika namun terdapat pendefinisian yang kurang dengan tepat, sudah lebih baik dari sebelumnya.

\section{Representation}

Pada pertemuan pertama siswa belum dapat mempresentasikan jawaban dengan gambar dan ukuran yang benar. Adanya perlakukan pembelajaran discovery learning, Nampak siswa dalam menggambar sketsa kubus yang terdapat pada soal dengan ukuran proporsional sesuai soal tetapi tidak menuliskan panjang rusuk dari kubus tersebut.

\section{Reasoning and argument}

Dari pertemuan satu sampai terakhir, selama diberi perlakuan dalam reasoning and argument belum nampak ada perubahan, siswa belum memberikan kesimpulan untuk mengecek ulang jawaban yang telah dikerjakan. Setelah menjawab dan perhitungan selesai, siswa menganggap selesai sudah pekerjaan.

\section{Devising strategies for solving problems}

Langkah-langkah penyelesaian benar terlihat dari adanya volume dari loyang saja, yang dikerjakan baru satu hal, yang diminta dalam soal belum ada jawaban.

\section{Using symbolic, formal and technical language and operations}

Menggunakan simbol, bahasa formal dan bahasa teknis serta operasi hitung untuk merumuskan, memecahkan atau menafsirkan matematika yaitu penulisan huruf/simbol benar, penulisan angka salah, tulisan tidak jelas. 


\section{Using mathematical tools}

Dalam perhitungan siswa menggunakan tidak menggunakan alat bantu perhitungan.

Gaya belajar tipe converger

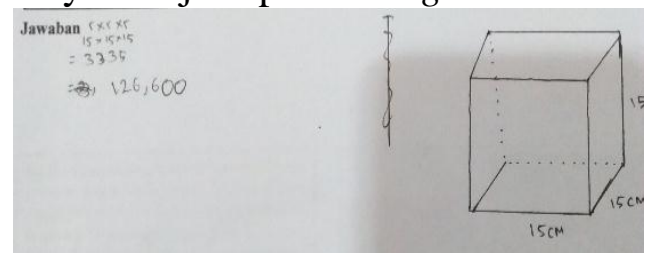

\section{Communication}

Pertemuan pertama siswa belum dapat menyampaikan gagasan dengan benar, setelah 4 kali pertemuan dengan pembelajaran discovery learning pendekatan RME, terlihat aspek communication. Setelah diberi perlakuan, siswa dalam menyatakan gagasan/ ide matematika sesuai dengan masalah yaitu menuliskan gagasan/ide pada soal dengan benar namun kurang lengkap. Siswa dalam memahami, menafsikan dan mengevaluasi gagasan/ ide matematika berkaitan dengan masalah yaitu rumusan benar dalam menjawab volume kubus dan hasilnya benar, tetapi tidak terlihat untuk apa mencari volume, langkah selanjutnya belum ada.

\section{Mathematising}

Pertemuan pertama siswa dalam mengubah permasalahan dari dunia nyata ke bentuk matematika masih kesusahan. Setelah diberi perlakukan secara berulang-ulang siswa dalam mengerjakan soal dapat mengubah permasalahan dari dunia nyata ke bentuk matematika namun terdapat pendefinisian yang kurang dengan tepat, sudah lebih baik dari sebelumnya.

\section{Representation}

Pada pertemuan pertama siswa belum dapat mempresentasikan jawaban dengan gambar dan ukuran yang benar. Adanya perlakukan pembelajaran discovery learning, Nampak siswa dalam menggambar sketsa kubus yang terdapat pada soal dengan ukuran proporsional sesuai soal tetapi tidak menuliskan panjang rusuk dari kubus tersebut.

\section{Reasoning and argument}

Dari pertemuan satu sampai terakhir, selama diberi perlakuan dalam reasoning and argument belum nampak ada perubahan, siswa belum memberikan kesimpulan untuk mengecek ulang jawaban yang telah dikerjakan. Setelah menjawab dan perhitungan selesai, siswa menganggap selesai sudah pekerjaan.

\section{Devising strategies for solving problems}

Langkah-langkah penyelesaian benar terlihat dari adanya volume dari loyang saja, yang dikerjakan baru satu hal, yang diminta dalam soal belum ada jawaban, belum ada diketahui dan ditanya dari jawaban.

\section{Using symbolic, formal and technical language and operations}

Menggunakan simbol, bahasa formal dan bahasa teknis serta operasi hitung untuk merumuskan, memecahkan atau menafsirkan matematika yaitu penulisan huruf/simbol benar, penulisan angka salah, tulisan tidak jelas.

\section{Using mathematical tools}

Dalam perhitungan siswa menggunakan tidak menggunakan alat bantu perhitungan. 


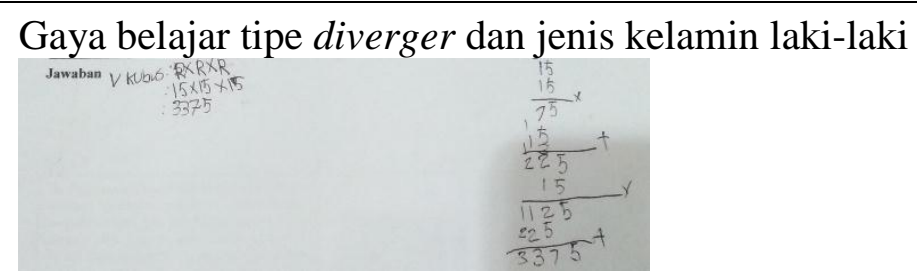

\section{Communication}

Pertemuan pertama siswa belum dapat menyampaikan gagasan dengan benar, setelah 4 kali pertemuan dengan pembelajaran discovery learning pendekatan RME, terlihat aspek communication. Setelah diberi perlakuan, siswa dalam menyatakan gagasan/ ide matematika sesuai dengan masalah yaitu menuliskan gagasan/ide pada soal dengan benar namun kurang lengkap. Siswa dalam memahami, menafsikan dan mengevaluasi gagasan/ ide matematika berkaitan dengan masalah yaitu rumusan benar dalam menjawab volume kubus dan hasilnya benar, langkah selanjutnya apa tidak jelas.

\section{Mathematising}

Pertemuan pertama siswa dalam mengubah permasalahan dari dunia nyata ke bentuk matematika masih kesusahan. Setelah diberi perlakukan secara berulang-ulang siswa dalam mengerjakan soal dapat mengubah permasalahan dari dunia nyata ke bentuk matematika namun terdapat pendefinisian yang kurang dengan tepat, sudah lebih baik dari sebelumnya.

\section{Representation}

Pada pertemuan pertama siswa belum dapat mempresentasikan jawaban dengan gambar dan ukuran yang benar. Adanya perlakukan pembelajaran discovery learning, ternyata tidak ada perubahan, tidak bisa membuat jawaban berupa gambar.

\section{Reasoning and argument}

Dari pertemuan satu sampai terakhir, selama diberi perlakuan dalam reasoning and argument belum nampak ada perubahan, siswa belum memberikan kesimpulan untuk mengecek ulang jawaban yang telah dikerjakan. Setelah menjawab dan perhitungan selesai, siswa menganggap selesai sudah pekerjaan.

\section{Devising strategies for solving problems}

Langkah-langkah penyelesaian benar terlihat dari adanya volume dari loyang saja, yang dikerjakan baru satu hal, yang diminta dalam soal belum ada jawaban, belum ada diketahui dan ditanya dari jawaban.

\section{Using symbolic, formal and technical language and operations}

Menggunakan simbol, bahasa formal dan bahasa teknis serta operasi hitung untuk merumuskan, memecahkan atau menafsirkan matematika yaitu penulisan huruf/simbol benar, penulisan angka salah, tulisan tidak jelas.

\section{Using mathematical tools}

Dalam perhitungan siswa menggunakan alat bantu perhitungan dengan susun pendek untuk mengalikan hasil volume.

\section{Kesimpulan}

Kemampuan literasi matematika siswa berdasarkan gaya belajar siswa kelas $\mathrm{V}$ Madrasah Ibtidaiyah dengan pembelajaran discovery learning pendekatan RME yaitu communication siswa dengan gaya belajar accommodator lebih baik dibandingan gaya belajar yang lainnya, gaya belajar converger paling jelek dibandingkan assimilator dan diverger, mathematizing siswa dengan gaya belajar 
accommodator lebih baik dibandingan gaya belajar yang lainnya, representation siswa dengan gaya belajar accommodator lebih baik dibandingan gaya belajar yang lainnya, reasoning and argument dari keempat gaya belajar belum muncul, devising strategies for solving problems dari keempat gaya belajar, gaya belajar yang lebih baik adalah accommodator walaupun apa yang diketahui dan ditanya dari setiap permasalahan belum muncul, using symbolic, formal and technical language and operations siswa dengan gaya belajar accommodator lebih baik dibandingan gaya belajar yang lainnya, using mathematical tools siswa dengan gaya belajar accommodator lebih baik dibandingan gaya belajar yang lainnya, digaya belajar converger tidak muncul sama sekali.

\section{Daftar Pustaka}

Hall, J. \& Matthews, E. 2008. The Measurement of Progress and The Role of Education. European Journal of Education. Vol. 43 No. 1.

Imam. G. (2013). Metode Kualitatif Teori \& Praktik. Jakarta: Bumi Aksara. Hlm. 155

Junaedi, I. \& Asikin, M. (2012). Pengembangan Pembelajaran Matematika Humanistik untuk Meningkatkan Kemahiran Matematis. Unnes Journal of Mathematics Education Research, 1(2)

Kunandar. (2007). Guru Profesional. Implementasi Kurikulum Tingkat Satuan Pendidikan (KTSP) dan Sukses dalam Sertifikasi Guru. Jakarta : PT Raja Grafindo Persada.

OECD, (2000). Measure student knowledge and skill: The PISA 2000 assessment of reading mathematical and scientific literacy. Paris: OECD

OECD. (2003). PISA 2003 Assessment Framework. http://www.oecd.org (24 Oktober 2016)

OECD. (2012). "PISA 2012 Results: What Students Know and Can Do".OECD Publication, vol. 1. http://www.oecd.org. (24 Oktober 2016)

OECD. (2013). PISA 2012 Results in Focus: What 15-years-old know and what they can do with what they know. Tersedia di http://www.oecd.org/pisa/keyfindings/pisa2012-result-overview.pdf (diunduh 15 November 2016)

OECD. (2016). "PISA 2015 Results (Volume 1): Excellence and Equity in Education". PISA. Paris: OECD Publishing. http://dx.doi.org/10.1787/9789264266490-en (diunduh 8 November 2017)

OECD. (2017). "PISA 2015 Assesment and Analytical Framework:Science, Reading, Mathematic, Financial Literacy and Collaborative Problem Solving, revised edition. PISA. Paris: OECD Publishing. http://dx.doi.org/10.1787/9789264281820-en (diunduh 10 Oktober 2017) 
Pratiwi, dkk. (2010). Konstruksi Tes Gaya Belajar Berdasarkan Teori Belajar Eksperiensial David A. Kolb. Jurnal interaksi, Vol. 1.1. file:///F:/penelitian\%202018/artikel\%20pratiwi.pdf

Syah, M. (2016). Psikologi Pendidikan dengan Pendekatan Baru. Bandung: PT Remaja Rosdakarya.

Sudjana, N. (2009). Penilaian Hasil Proses Belajar Mengajar. Bandung: Remaja Rosdakarya. 